\title{
Prymat papieski a zakres autonomii zebrań biskupów
}

Sobór Watykański II mówi w konstytucji dogmatycznej o Kościele Lumen gentium o wspólnotowej naturze Kościoła, która uzewnętrznia się między innymi w kolegialnym charakterze i naturze episkopatu. Od czasów starożytnych biskupi gromadzili się na soborach i synodach w celu kolegialnego rozstrzygania problemów, których nie mogli rozwiązać sami wewnątrz swojego Kościoła lokalnego, oraz tych spraw, które były wspólne dla wszystkich Kościołów. Zbierali się także wspólnie, aby dokonać wyboru kandydatów do godności biskupiej ${ }^{1}$.

Sobór zaznacza jednak, że „Kolegium, czyli ciało biskupie, posiada władzę autorytatywną jedynie wtedy, gdy pozostaje w łączności z Biskupem Rzymu, Następcą Piotra, jako jego Głową, i gdy nienaruszony pozostaje jego prymat wobec wszystkich pasterzy i wiernych" ${ }^{2}$. Do tego sformułowania konstytucji Lumen gentium nawiązuje Kodeks prawa kanonicznego, kan. $337 \$ 2-3$. Szczególnie istotny dla poruszonej w niniejszym wystąpieniu problematyki wydaje się $\$$ 3, który stanowi, że do „Biskupa Rzymu należy, stosownie do potrzeb Kościoła, dobieranie i popieranie sposobów wykonywania przez Kolegium Biskupów jego zadania w całym Kościele”.

I Por. LG 22; O. Bucci, Il Collegio dei Vescovi nelle sue origini, [w:] Ius Ecclesiarum vehiculum caritatis. Atti del simposiointernazionale per il decennale dell'entrata in vigore del Codex Canonum Ecclesiarum Orientalium (Città del Vaticano 19-23 novembre 2001), red. S. Agrestini, D. Ceccarelli Morolli, Città del Vaticano 2004, s. 221.

2 LG 22. 
Taka kolegialność, a właściwie synodalność, co wydaje się terminem bardziej odpowiednim, przekłada się na płaszczyznę komunii Kościołów lokalnych, na których czele stoją poszczególni biskupi, Kościołów, z których się składa jeden i jedyny Kościół katolicki ${ }^{3}$. I to również należy mieć na względzie, podejmując temat zakresu autonomii zebrań biskupów w odniesieniu do prymatu papieskiego.

Pojęcie zebrań biskupów jest szerokie i obejmuje wielorakie formy kolegialnego działania biskupów, praktycznie od soboru powszechnego, przez synody partykularne, Konferencje Biskupów i zgromadzenia hierarchów różnych Kościołów sui iuris oraz synody Kościołów wschodnich.

Zgromadzeniem biskupów, w którym najpełniej uwidacznia się kolegialność episkopatu jest sobór powszechny. To na nim Biskup Rzymu jako Głowa Kolegium i biskupi będący z nim w hierarchicznej wspólnocie wykonują w sposób uroczysty władzę w całym Kościele ${ }^{4}$. Biorąc pod uwagę ograniczony czas wystąpienia, przypomnę tylko, że sobór może być zwołany wyłącznie przez Biskupa Rzymskiego, który mu przewodniczy osobiście lub przez innych, a jeśli w czasie trwania soboru zawakowałaby Stolica Apostolska, na mocy samego prawa sobór zostaje przerwany. Tylko Biskup Rzymski może sobór przenieść, zawiesić, rozwiązać, jak również zatwierdzać jego dekrety 5 .

Nie inaczej jest w przypadku Synodu Biskupów powołanego do istnienia przez papieża Pawła VI 15 września 1965 roku, który od samego początku jest złączony strukturalnie z osobą Biskupa Rzymu. Ma mu świadczyć pomoc swoją radą, a zarazem umacniać z nim łączność Kolegium Biskupów ${ }^{6}$.

W niniejszym wystąpieniu skoncentrujemy się na synodach partykularnych i Konferencjach Biskupów - instytucjach typowych dla Kościoła łacińskiego oraz na synodach Kościołów patriarchalnych i arcybiskupich większych, wspominając pokrótce także radę hierarchów Kościołów metropolitalnych sui iuris i inne zebrania biskupów, mające dzisiaj mniejsze znaczenie.

3 Por. LG 23; S. Piè-Ninot, La dimensione sinodale della missione episcopale e le sue intrinseche esigenze. Un apporto dell'ecclesiologia per la canonistica contemporanea, [w:] Strutture sovraepiscopali nelle Chiese Orientali, red. L. Sabbarese, Roma 2011, s. 14-15.

4 Por. kan. $337 \$ 1 \mathrm{KPK}$.

5 Por. kan. 338, 340 KPK.

6 Por. kan. 342 KPK. 


\section{Synody partykularne}

Synody partykularne sięgają swoimi początkami II wieku i odegrały doniosłą rolę $\mathrm{w}$ dziedzinie nauczania prawd wiary oraz określenia dyscypliny kościelnej. Były, obok soborów powszechnych, formą rządzenia Kościołem, a zarazem prawdziwą rapraesentatio Ecclesiae i praktycznym wyrazem kolegialności episkopatu? ${ }^{7}$ W odróżnieniu od Konferencji Episkopatu, która działa zarówno przez zgromadzenie plenarne złożone ze wszystkich jej członków, jak i przez prezydium, radę stałą, sekretarza czy inne organy, które są jedynie namiastką kolegialności, synody partykularne są zawsze wyrazem kolegialności episkopatu danego terytorium ${ }^{8}$. Stąd chociaż obecnie stracily na znaczeniu, a ich tradycyjne prerogatywy przejęly w części Konferencje Episkopatu, Kodeks prawa kanoniczengo umieszcza je przed nimi.

Kodeks mówiąc o synodach partykularnych, do których zalicza synod plenarny i synod prowincjalny, definiuje je jako zebranie biskupów zwołane ilekroć uznane zostanie to za konieczne lub pożyteczne. Mogą zostać na nie wezwani także inni duchowni, zakonnicy i świeccy, lecz jedynie z głosem doradczym? ${ }^{9}$.

Stolica Apostolska, świadoma znaczenia synodów partykularnych, sprawowała nad nimi w ciągu wieków różnorodne formy nadzoru w celu zapewnienia ich komunii z Biskupem Rzymu oraz zagwarantowania prymacjalnego charakteru jego urzędu. Czuwała jednocześnie nad poprawnością postanowień synodalnych i nad tym, by uwzględniały one priorytety określone nauczaniem papieża i soborów, co było szczególnie widoczne po Soborze Trydenckim.

Nawiązując do wspomnianej praktyki, której motywy pozostają aktualne, kan. 439 kodeksu stanowi, że zwołanie synodu plenarnego dla wszystkich Kościołów partykularnych tej samej Konferencji Episkopatu oraz synodu prowincjalnego odbywanego w prowincji kościelnej, której granice pokrywają się z granicami kraju, wymaga uprzedniej aprobaty Stolicy Apostolskiej. W przypadku synodu plenarnego jej aprobatę musi uzyskać także biskup diecezjalny

7 Por. DB 36; G. Ruggieri, I Sinodi tra storia e teologia, [w:] Chiesa e sinodalità, red. R. Battocchio, S. Noceti, Milano 2007, s. 129-161.

8 Por. G. Rossi, Commento all'art. 82 PB, [w:] Commento alla Pastor Bonus e alla e norme sussidiarie della Curia Romana, red. P.V. Pinto, Città del Vaticano 2003, s. 115-116.

9 Por. kan. 439-443 KPK. 
wybrany na przewodniczącego synodu ${ }^{10}$. Po zakończeniu synodu zarówno plenarnego, jak i prowincjalnego, jego przewodniczący ma przesłać wszystkie akta zgromadzenia do Stolicy Apostolskiej. Promulgacja uchwał synodalnych możliwa jest dopiero po otrzymaniu recognitio Stolicy Apostolskiej ${ }^{11}$.

Interwencja Stolicy Apostolskiej nazywana recognitio polega na szczegółowej i uważnej analizie dokumentu i jego ocenie. Ma ona na celu zagwarantowanie zgodności tworzonego prawa partykularnego z prawem powszechnym, zapewnienie poprawności doktrynalnej oraz zgodności tłumaczeń tekstów liturgicznych na języki narodowe, ocenę, czy dany dokument względnie lokalne adaptacje liturgiczne są pożyteczne. Chodzi jednocześnie o umocnienie jedności Kolegium Biskupów i jego komunii z Biskupem Rzymu, następcą św. Piotra ${ }^{12}$.

\section{Konferencje Biskupów}

Kodeks prawa kanonicznego w kan. 447 określa Konferencję Episkopatu jako „zebranie biskupów jakiegoś kraju lub określonego terytorium wypełniających wspólnie pewne zadania pasterskie dla wiernych jej terytorium, w celu pomnożenia dobra udzielanego ludziom przez Kościół, głównie przez odpowiednio przystosowane do bieżących okoliczności czasu i miejsca formy i sposoby apostolatu, z zachowaniem przepisów prawa”. Kolejne normy kodeksowe precyzują pojęcie terytorium oraz strukturę i członków Konferencji. Istnieją więc Konferencje Episkopatu narodowe, międzynarodowe i regionalne w obrębie tego samego kraju ${ }^{13}$.

Kodeks prawa kanonicznego w kan. $449 \$ 1$ stanowi, że tylko „najwyższa władza kościelna ma prawo po wysłuchaniu zainteresowanych biskupów, do erygowania Konferencji Episkopatu, znoszenia ich i dokonywania w nich zmian”. Określenie „najwyższa władza kościelna” odnosi się do Biskupa Rzymu. W praktyce oznacza to, że chociaż prefekt Kongregacji Biskupów, Kon-

ro Por. kan. $441,3^{\circ} \mathrm{KPK}$.

II Por. kan. $446 \mathrm{KPK}$. Odmiennie niż w przypadku dekretów ogólnych Konferencji Episkopatu, kanon nie uzależnia ich mocy prawnej od recognitio.

${ }_{12}$ Por. Papieska Rada ds. Testów Prawnych, Nota wyjaśniająca na temat natury prawnej i zakresu „recognitio” Stolicy Świętej, „Communicationes”, 2006, t. 38, s. 10-17.

r3 Por. „Annuario Pontificio 2011”, Città del Vaticano 2011, s. 1082-1099. 
gregacji Kościołów Wschodnich czy Kongregacji Ewangelizacji Narodów posiada kompetencje w stosunku do podlegających dykasterii Konferencji Episkopatów, to jeżeli chodzi o ich erygowanie, znoszenie i dokonywanie zmian, wymagana jest osobista interwencja papieża ${ }^{14}$. Wynika to z cytowanego już wcześniej kan. $337 \$ 3$ kodeksu. Oddziaływanie poszczególnych Konferencji Episkopatu wykracza bowiem poza obszar ich statutowego terytorium i ma wpływ na Kościół powszechny ${ }^{15}$.

Statuty Konferencji Episkopatu względnie poprawki do nich oraz niektóre dokumenty, które zostały przyjęte przez Konferencję, potrzebują przed promulgacją recognitio Stolicy Apostolskiej. Po każdej sesji plenarnej przewodniczący Konferencji winien przesłać Stolicy Apostolskiej za pośrednictwem Nuncjatury Apostolskiej relację o aktach Konferencji oraz ewentualne dokumenty, o których była mowa wyżej ${ }^{16}$.

Trzeba tutaj zaznaczyć, że Konferencja Episkopatu nie posiada ze swojej natury władzy ustawodawczej. Zgodnie z kan. 455 może ona wydawać dekrety ogólne jedynie w sprawach, w których przewiduje to prawo powszechne. Może je wydawać również na wyraźne polecenie Stolicy Apostolskiej lub za jej zgoda, która deroguje w ten sposób normy kodeksu ${ }^{17}$.

Motu proprio Apostolos suos wydane przez papieża bł. Jana Pawła II 21 maja 1998 roku określiło ponadto zasady wydawania przez Konferencje Episkopatu deklaracji doktrynalnych, dotyczących nowych kwestii związanych z przemianami w świecie. Jeżeli zostały one przyjęte jednogłośnie przez członków Konferencji posiadających głos decydujący, mają dla danego terytorium walor nauczania autentycznego. Jeśli nie, konieczne jest przed promulgacją

I4 Kiedy KPK i KKW mówią o „Stolicy Apostolskiej” i Stolicy Świętej”, oznacza to jedną z dykasterii Kurii Rzymskiej, które na mocy konst. apost. Pastor Bonus i specjalnych uprawnień otrzymanych od papieża z reguły na początku każdego pontyfikatu, posiada kompetencję w danej materii. Niezależnie od tego, jej prefekt lub przewodniczący ma obowiązek informowania ojca świętego o decyzjach podjętych w ważniejszych sprawach, a czasami wymagana jest uprzednia aprobata papieża. Por. G. Rossi, Commento..., dz. cyt.

${ }_{15}$ Por. A. Damizia, Commento al can. 449, [w:] Commento al Codice di Diritto Canonico, red. P.V. Pinto, Città del Vaticano 2001, s. 266.

I6 Por. kan. 456 KPK.

17 Uznanie przez Stolicę Apostolską aktów Konferencji Biskupów nie zmienia kwalifikacji jej działania. J. Krzywda, Prymat papieski i Kolegium Biskupów w świetle nauki Vaticanum I i II, Kraków 2008, s. 280. 
dokumentu otrzymanie recognitio Stolicy Apostolskiej. W tym przypadku wymagane jest przyjęcie dokumentu przynajmniej większością kwalifikowaną ${ }^{18}$.

Recognitio Stolicy Apostolskiej jest ponadto konieczna w przypadku tłumaczeń na języki narodowe ksiąg liturgicznych i wprowadzenia do nich lokalnych przystosowan ${ }^{19}$ czy opracowania własnego obrzędu zawierania małżeństwa ${ }^{20}$.

Jeżeli chodzi o działalność Konferencji Episkopatu, w niektórych wypadkach kodeks mówi o potrzebie aprobaty ze strony Stolicy Apostolskiej ${ }^{21}$. Jest ona konieczna np. w przypadku erygowania seminarium międzydiecezjalnego dla całego terytorium Konferencji ${ }^{22}$, czy wydania katechizmów dla własnego terytorium ${ }^{23}$. Podobnie jak w wyżej wymienionych sytuacjach, chodzi tutaj o decyzje mające istotne znaczenie dla Kościołów lokalnych reprezentowanych w Konferencji przez swoich biskupów.

\section{Synody Biskupów Kościołów patriarchalnego i arcybiskupiego większego}

Struktura organizacyjna katolickich Kościołów wschodnich związana jest ściśle z ich statusem prawnym. W przypadku Kościołów patriarchalnych i arcybiskupich większych uwzględnia ona szeroki zakres władzy patriarchy i arcybiskupa większego oraz synodu biskupów danego Kościoła.

Sobór Watykański II mówi, że: „Patriarchowie wraz ze swoimi synodami tworzą zwierzchnią instancję dla wszelkiego rodzaju spraw patriarchatu, nie wyłączając prawa ustanawiania nowych eparchii i mianowania biskupów

${ }^{\text {I8 }}$ Por. Jan Paweł II, motu proprio Apostolos suos, AAS, 1998, vol. 90, s. 641-658; por. kan. 753 KPK.

19 Por. kan. $838 \$ 3 \mathrm{KPK}$; kan. $657 \$ 1 \mathrm{KKKW}$.

20 Por. kan. $1120 \mathrm{KPK}$.

${ }^{21}$ Chociaż niektórzy autorzy utożsamiają recognitio z aprobatio, aprobata wydaje się zakładać wcześniejszą rewizję dokumentu czy ocenę złożonego wniosku. Por. Papieska Rada ds. Tekstów Prawnych, Nota wyjaśniająca, dz. cyt.; P. Krämer, La Conferenza episcopale e la Sede Apostolica, [w:] Natura e futuro delle Conferenze episcopali. Atti del Colloquio internazionale di Salamanca (3-8 gennaio 1988), red. H. Legrand, J. Manzanares, A. Garcia y Garcia, Bologna 1988, s. 152-153; F. J. Ramos, Le Chiese particolari e i loro raggruppamenti, Roma 2000, s. 385-386. $\$ 2 \mathrm{KPK}$.

${ }^{22}$ Aprobacie Stolicy Apostolskiej podlegają także statuty tego seminarium. Por. kan. 237

23 Por. kan. $775 \$ 2$ KPK. 
swojego obrządku w granicach terytorium patriarchatu, przy zachowaniu niezbywalnego prawa Biskupa Rzymu do interweniowania w poszczególnych przypadkach" 24 .

Sobór stwierdza jednocześnie, że: „to co powiedziano o patriarchach, według norm prawa dotyczy także arcybiskupów większych" 25 . Tak samo stanowi kan. 152 Kodeksu kanonów Kościołów wschodnich [dalej: KKKW], dopuszczając pewne wyjątki określone przez prawo wspólne ${ }^{26}$.

Biorąc pod uwagę temat niniejszego wystąpienia, skoncentrujemy się na działalności Synodu Biskupów Kościoła patriarchalnego i Kościoła arcybiskupiego większego.

Należą do niego wszyscy biskupi wyświęceni tego Kościoła, gdziekolwiek ustanowieni. Z wyjątkiem tych, którzy są niezdatni do aktu ludzkiego, nie są w jedności kościelnej oraz ciążą na nich najcięższe kary kanoniczne, powinni być oni wezwani na posiedzenie synodu ${ }^{27}$.

Synod posiada bardzo szerokie uprawnienia, spośród których należałoby wymienić na pierwszym miejscu wybór głowy danego Kościoła i biskupów. Dziedzina ta jest jedną z tych, gdzie uwidacznia się „niezbywalne prawo Biskupa Rzymu do interweniowania w poszczególnych przypadkach”, jak mówi cytowany wcześniej dekret soborowy o katolickich Kościołach wschodnich.

Bardzo znamienna jest procedura wyboru patriarchy, który jest głową i ojcem Kościoła patriarchalnego ${ }^{28}$. Jego wyboru dokonuje Synod Biskupów Kościoła patriarchalnego. Wybrany zostaje ten, kto otrzymał dwie trzecie głosów, chyba że zgodnie z prawem partykularnym, po przynajmniej trzech bezskutecznych głosowaniach, wystarcza bezwzględna większość głosów. Gdyby w ciąu 15 dni od rozpoczęcia synodu nie udało się wybrać patriarchy, sprawa zostaje przekazana papieżowi, który może zwołać nowy synod, mianować osobiście patriarchę lub podjać inne decyzje. Jeśli wybrany przez synod jest biskupem i przyjmuje wybór, następuje jego ogłoszenie i intronizacja. Powinien on jednocześnie poprosić jak najszybciej Biskupa Rzymskiego, który jest Głową Kościoła i Kolegium Biskupów, o udzielenie znaku wspólnoty kościelnej (ecclesiastica

\footnotetext{
24 DKW 9.

${ }_{25}$ DKW 10.

26 Chodzi tu gównie o procedurę powołania arcybiskupa większego.

${ }_{27}$ Por. kan. 102 KKKW.

${ }_{28}$ Por. DKW 9; kan. 55 KKKW.
} 
communio). Przed jej otrzymaniem, co dokonuje się przez dokument podpisany ręką papieża, ma nie zwoływać synodu i nie wyświęcać biskupów ${ }^{29}$.

Podobna procedura obowiązuje w przypadku wyboru arcybiskupa większego, jednak inaczej niż w przypadku patriarchy, elekt musi otrzymać po wyborze zatwierdzenie papieża. Jeśli go odmówiono, wybór nowego arcybiskupa większego ma zostać dokonany w czasie określonym przez papieża ${ }^{30}$.

Wyboru biskupów, którzy mają pełnić swe funkcje w granicach terytorium Kościoła patriarchalnego i arcybiskupiego większego, dokonuje Synod Biskupów tego Kościoła. W przypadku biskupów może on wybrać jednego kandydata na konkretną eparchię lub urząd albo wielu kandydatów bez określania zadań, do jakich są oni przewidywani. W obu przypadkach konieczne jest następnie uzyskanie zgody papieża. Po jej otrzymaniu, jeśli wybrany na konkretny urząd wyrazi zgodę, może zostać ogłoszony i przyjąć święcenia biskupie. W przypadku zatwierdzenia przez papieża kilku kandydatów, jeśli aprobata papieska nie została odwołana w późniejszym czasie, synod może wybierać spośród nich biskupów w zależności od istniejących potrzeb, powiadamiając o tym Stolicę Apostolską ${ }^{31}$. Poza granicami terytorium Kościoła patriarchalnego lub arcybiskupiego większego jego biskupi mianowani są przez papieża, któremu Synod Biskupów przedstawia ternę kandydatów ${ }^{32}$.

Synod Kościoła patriarchalnego i arcybiskupiego większego posiada władzę ustawodawczą. Jego ustawy i decyzje powinny być jak najszybciej przesłane Biskupowi Rzymskiemu. Poza wyjątkami, o których niżej, nie wymagają jego aprobaty, jednak sam obowiązek poinformowania Głowy Kolegium Biskupów, stwarza możliwość interwencji ${ }^{33}$. Aprobata papieża jest konieczna w przypadku ustaw i decyzji dotyczących wykonywania przez patriarchę/arcybiskupa większego władzy poza granicami terytorium jego Kościoła oraz gdy określają one inne niż w prawie powszechnym zasady wyłonienia oraz wyboru kandydatów do godności biskupiej ${ }^{34}$. Natomiast jeżeli synod zdecyduje o zniesieniu lub o przeniesieniu na niedzielę dnia świątecz-

29 Por. kan. 63-77 KKKW.

3० Por. kan. 153 KKKW.

$3^{\mathrm{I}}$ Por. kan. 181-185 KKKW.

32 Por. kan. $181 \$ 2$ KKKW.

33 Por. kan. 110-111 KKKW; K. Bharanikulangara, Particular law of the Eastern Catholic Churches, New York 1996, s. 32-33.

34 Por. kan. $78 \$ 2$; $182 \$ 3$ KKKW. 
nego oraz gdy wyda odmienne od prawa powszechnego normy dotyczące odwołania lub przeniesienia proboszczów, konieczne jest zatwierdzenie Stolicy Apostolskiej ${ }^{35}$. Należy zauważyć, że ustawy i decyzje synodu obowiązują w granicach terytorium Kościoła patriarchalnego/arcybiskupiego większego, natomiast ustawy liturgiczne - wszędzie. Biskupi eparchialni ustanowieni poza terytorium mogą nadać moc prawną we własnych eparchiach także pozostałym ustawom uchwalonym przez synod. Jeżeli uzyskały one aprobatę Stolicy Apostolskiej, posiadają moc prawną wszędzie ${ }^{36}$.

Synod Biskupów jest ponadto najwyższym trybunałem w granicach Kościoła patriarchalnego, z zachowaniem kompetencji Stolicy Apostolskiej. Do niego należy rozstrzyganie spraw spornych eparchii i biskupów ${ }^{37}$.

\section{Rada hierarchów Kościoła metropolitalnego sui iuris}

Rada ta składa się z wyświęconych biskupów Kościoła metropolitalnego. Nie posiada ona władzy wybierania biskupów, jak synody patriarchalne i arcybiskupie większe. Metropolita Kościoła metropolitalnego sui iuris oraz wszyscy jego biskupi mianowani są przez papieża, któremu rada hierarchów przedstawia każdorazowo przynajmniej trzech kandydatów ${ }^{38}$.

Rada posiada natomiast władzę ustawodawczą w zakresie prawa partykularnego. Jednak przed promulgacją ustaw i norm, metropolita - bowiem to do jego kompetencji należy ich promulgowanie - winien jak najszybciej zawiadomić Stolicę Apostolską i otrzymać pisemne zawiadomienie o przyjęciu decyzji rady ${ }^{39}$.

\section{Zgromadzenie hierarchów Kościołów sui iuirs}

Zgodnie z kan. 322 KKKW skupia ono hierarchów katolickich Kościołów wschodnich i Kościoła łacińskiego wykonujących swoją władzę w tym samym narodzie lub regionie. Kompetentna w jego ustanowieniu i zatwier-

35 Por. kan. $880 \$ 3$; 1388 KKKW.

$3^{6}$ Por. kan. $110 \$ 1 ; 112 \$ 1 ; 150 \$ 2$ i 3 KKKW.

37 Por. kan. $110 \$ 2 ; 1062 \mathrm{KKKW}$.

$3^{8}$ Por. kan. $155 \$ 2 ; 164 ; 168$ KKKW.

39 Por. kan. 167 KKKW; K. Bharanikulangara, Particular law..., dz. cyt., s. 33-34. 
dzeniu statutów jest Stolica Apostolska. Z uwagi na odmienną strukturę Kościołów i różnorodność obrządków, które reprezentują przynależący do wspomnianego zgromadzenia patriarchowie i biskupi, służy ono raczej umacnianiu wzajemnej jedności pomiędzy różnymi Kościołami, wymianie doświadczeń i konsultacji, niż podejmowaniu jakichś konkretnych rozwiązań duszpasterskich. Jeśli uchwaliłoby jakieś postanowienia większością przynajmniej dwóch trzecich głosów członków posiadających głos czynny, aby miały one moc prawną, muszą zostać zatwierdzone przez Stolicę Apostolską. Zgromadzenie hierarchów nosi czasami nazwę Konferencji Episkopatu i przypomina ją w swoim działaniu ${ }^{40}$.

\section{Zakończenie}

Niniejsze wystąpienie miało na celu przedstawienie różnych rodzajów zebrań biskupów i zakresu ich autonomii. Bez względu na to, w czym się ona wyraża i jak bardzo jest szeroka, pozostaje nienaruszony prymat Biskupa Rzymu wobec wszystkich pasterzy i wiernych oraz jego funkcja Głowy Kolegium Biskupów. Zakończę słowami, jakie wypowiedział 22 listopada 2001 roku ówczesny Sekretarz Stanu kard. Angelo Sodano podczas sympozjum poświęconemu dziesięcioleciu promulgacji KKKW: „W Kościele Chrystusa nie istnieje żadna władza ponadbiskupia, a tym bardziej ponadmetropolitalna, poza tą najwyższą, jaką Chrystus powierzył Piotrowi i jego następcom”¹.

40 Por. „Annuario Pontificio 2011”, s. 1100-1101; M. Brogi, Sinodi Patriarcali, Assemblee e Conferenze Episcopali di rito orientale, „Antonianum”, 1976, vol. 51, s. 250-265.

${ }^{4}$ A. Sodano, Discorso ai partecipanti al Simposio, [w:] Ius Ecclesiarum vehiculum caritatis, dz. cyt., s. 588 . 


\section{The Pope's Primacy and the Autonomy of Groups of Bishops}

Summary

The aim of the paper is to present all sorts of groups of bishops and levels of their autonomy in confrontation with primacy of the Pope. The conclusion is that the supreme, full, immediate and universal ordinary power of the Pope in the Church is not limited, but rather strengthened by the power of the bishops gathered together.

Keywords: group of bishops, pope, power, Church, primacy 
